\title{
VISITORS’ MOTIVES FOR ATTENDING A HYBRID EVENT: A CASE STUDY OF AGRICULTURAL FAIR
}

\author{
Milan Ivkov ${ }^{1}$, Ivana Blešić2 ${ }^{2}$ Jovanka Popov Raljićc \\ Anđelija Ivkov Džigurski ${ }^{4}$, Tatjana Pivac ${ }^{5}$, Tamara Jovanovićc
}

\begin{abstract}
Summary
Management of a complex events such as hybrid ones, relies on understanding a modern market trends. The purpose of this study is to determine visitors' motives for attending a hybrid event, to identify clusters based on those motives, and to help organizers and exhibitors to meet visitors' expectations. Therefore, authors performed ANOVA analysis, factor analysis and hierarchical cluster analysis. The findings clearly indicate elements of trade fairs and consumer exhibitions integrated in hybrid event and therefore, some of the main motives for visiting those two types of events are also present among hybrid event visitors. However, hybrid event tends to be more than just place for business meetings. It is also a venue for education and leisure time activities. Moreover, event organizers and exhibitors need to pay more attention on their strategic approach to managing their event activities. The paper suggests that hybrid event organizers should focus on establishing dialogue with both exhibitors and visitors.
\end{abstract}

Key words: hybrid event, visitors' motives, consumer exhibition, trade fair.

JEL: $Q 13, G 14, D 84, L 21$

1 Milan Ivkov, M.Sc., Professional Associate, University of Novi Sad, Faculty of Sciences, Department of Geography, Tourism and Hotel Management, Trg Dositeja Obradovića no. 3, 21000 Novi Sad, Serbia, Phone: +381 21485 2842, e-mail: ivkov.milan@gmail.com

2 Ivana Blešić, Ph.D., Assistant Professor, University of Novi Sad, Faculty of Sciences, Department of Geography, Tourism and Hotel Management, Trg Dositeja Obradovića no. 3, 21000 Novi Sad, Serbia, Phone: +381 21485 2835, e-mail: ivana.blesic@dgt.uns.ac.rs

3 Jovanka Popov Raljić, Ph.D., Full Professor, University of Novi Sad, Faculty of Sciences, Department of Geography, Tourism and Hotel Management, Trg Dositeja Obradovića no. 3, 21000 Novi Sad, Serbia, Phone: +381 21485 2884, e-mail: jovankaraljicpopov@gmail.com

4 Anđelija Ivkov Džigurski, Ph.D., Associate Professor, University of Novi Sad, Faculty of Sciences, Department of Geography, Tourism and Hotel Management, Trg Dositeja Obradovića no. 3, 21000 Novi Sad, Serbia, Phone: +381 21485 2834, e-mail: ivkova@uns.ac.rs

5 Tatjana Pivac, Ph.D., Associate Professor, University of Novi Sad, Faculty of Sciences, Department of Geography, Tourism and Hotel Management, Trg Dositeja Obradovića no. 3, 21000 Novi Sad, Serbia, Phone: +381 21485 2835, e-mail: tatjana.pivac@dgt.uns.ac.rs

6 Tamara Jovanović, Ph.D., Assistant Professor, University of Novi Sad, Faculty of Sciences, Department of Geography, Tourism and Hotel Management, Trg Dositeja Obradovića no. 3, 21000 Novi Sad, Serbia, Phone: +381 21485 2845, e-mail: jtamara@uns.ac.rs 


\section{Introduction}

Dynamic development of the market initiated fast growth of the event industry, and driven with constantly rising consumer needs, events have reached their blossom era in terms of variety and socio-economic importance. The impact of events can result in positive and negative direction, where the negative impacts and the unequal distribution of benefits are less commonly explored (Hiller, 1998).

Probably the most important impact is on tourism, especially if considered as its development tool. Exhibitions, fairs, festivals and all events in general, provide benefits for the local community visible before the event takes place, during the event and afterwards. Exhibitions boost positive impacts and share them throughout social, economic, cultural and even political dimensions. Due to this, events have become one of the fastest growing types of tourism attractions (Crompton, McKay, 1997; Getz, 1997; Thrane, 2002). Since the events have such a significant role in the local community, motives that attract visitors are interesting area for research. As long as we treat an event as a service or product, motives can be described as a link between the urge to satisfy the need and decision trigger. Many authors consider tourists' motives as multiple (Crompton, 1979; Pearce, 1982; Mansfeld, 1992; Uysal et al., 1993) which applies to hybrid event visitors in certain manner. Led by different motives, these events are visited by representatives of nonexhibiting companies, professional visitors, government and embassy delegates, various buyers and sellers and the general public. Event organizers put their efforts in attracting all groups of visitors offering them a wide range of services and emphasizing benefits arising from the visit.

The International Agriculture Fair in Novi Sad (Serbia) represents a multi-dimensional event recognized worldwide. It has grown into a leading event of this kind in the region positioning itself high among other similar events. As it has been the case so far, tourist organizations and sport associations traditionally participate in this event as well as sellers of consumer goods. Despite its main agricultural theme, the fair is recognized among the general public as a unique place for spending spare time. Professional lectures, round table sessions, workshops and other supporting activities organized at the Congress centre of the Novi Sad Fair add extra quality to this event.

To the authors' knowledge no previously published research has been statistically examined in terms of visitors' motives of visiting hybrid event of this kind.

This study focuses on visitors' main motivations for visiting the hybrid event and segmenting them in relation to their motives. The paper should identify major motives of visitor and help organizers and other stakeholders in creation of enhanced and successful exhibitions.

After the introduction as the first part of the manuscript, the paper explores published literature related to events, visitors' motives, and role of exhibition organizers and presents proposed hypotheses. Third part of the paper offers the insight of used methodology and sample characteristics. The following, fourth section of the paper presents the research 
results and authors' discussion. The last, fifth part of the paper deals with concluding thoughts with emphasis on practical implications, limitations of the study and suggestions for future research.

\section{Literature review and hypotheses}

\section{Events}

Together with the civilization development, events found their way to the frame of organized society. We can say that all today's events date back to that ancient period but their significance is nowadays much higher and multiple. Human society went through many different phases in history resulting in changes of consumers' behavior and visitors' decision making process, emerging new interests and increase of leisure time activities diversification. The great abundance of existing events requires a systematic approach to the selection process. Visitors have a task to recognize potential attractions and to decide which one to visit. Since many of the event organizers are faced with severe competition, strategies on how to attract visitors are crucial. In terms of financial income, visitors play another important role.

While the economic impact of the events is mainly significant to the local community, other benefits are of high importance for the country in general. A great part of world literature focuses on mentioned economic benefits but many authors (for example, Carlsen, Taylor 2003; Fredline et al., 2003) suggest more research is needed on the social, physical, environmental and tourism impacts of events and their interrelationships.

Rittichainuwat and Mair (2012) state that exhibitions can be subdivided into three categories: trade shows, consumer exhibitions and a hybrid category which combines two previously mentioned. Trade shows are described as open only to business/professional visitors and media representatives (Browning, Adams, 1988). Consumer exhibitions are open to the public and they allow direct sell-buy actions between exhibitors and consumers (Rittichainuwat, Mair, 2012). Following this classification, International Agriculture Fair belongs to the group of hybrid exhibitions. In order to better understand this event Table 1 shows its profile. Such exhibition complexity could be described as the response to market trends and to a growing interest and recognition of its value in terms of economy, society, culture and tourism.

Not only exhibitions attract visitors but also companies looking for a chance to extend their businesses. It is a unique opportunity to meet all significant stakeholders in one place, get more information on competition activities, to identify potential emerging trends and estimate further actions. From personal experience in organizing this and many other similar exhibitions, authors find these events as a very powerful tool in positioning the company on the market and creating a brand image. Another advantage of this marketing strategy is a direct contact between exhibiting companies and visitors, buyers and dealers which allows quick comparisons of products (Reeder et al., 1991) and effective interaction between exhibitors and visitors through many activities (Kozak, 2006; Pearce, 2007; Getz, 2008). From the visitors' point of view, Dwyer and Tanner (1999) state that this is an opportunity to obtain information from many vendors at one place. Fairs are places where exhibitors often present new product or services for the first time. This means visitors are able to see them, 
test them and to buy them usually at discount prices. Most of the sales made at the exhibition are direct (B2B or B2C).

Since the benefits of being present at such exhibition are numerous, competition among companies is constantly increasing (Gomez et al., 1992). Those benefits attract both exhibitors and visitors.

Table 1. Event profile

\begin{tabular}{|l|l|}
\hline \multicolumn{1}{|c|}{ Main exhibitor commodity groups } & \multicolumn{1}{c|}{ Supporting activities } \\
\hline Agriculture machinery & Seminars, workshops, etc. \\
\hline Seed material & Horse riding tournaments \\
\hline Chemical industry products & Thematic days (Day of cattle breeders, etc.) \\
\hline Livestock & Quality appraisal \\
\hline Animal feed & Pets exhibition \\
\hline Food and drink & Lottery/raffle \\
\hline Food processing equipment & Strongman Champions League (2011) \\
\hline Other & Other \\
\hline
\end{tabular}

Source: Authors' research

\section{Visitors' motives}

Benefits discussed in literature are: collecting information about new products (Rosson, Serinhaus, 1995); collecting information for future purchases (Munuera, Ruiz, 1999); comparing brands (Tanner et al., 2001); assessing new products and developments, obtaining product and technical information, meeting and comparing potential suppliers and gaining new ideas (Dudley, 1990). On the other hand, when deciding whether or not to visit an exhibition, potential visitors are concerned about the information they expect to find about products, services and companies (Blythe, 2002). Depending on the type of visitor, exhibitions can be considered as interactive business network - much more than selling/buying or communication tool (Bello, 1992; Bello, Lohita 1993; Rosson, Serinhaus, 1995; Ling Yee, 2007), and as an environment where business partners and suppliers can be evaluated (Sharland, Balgoh, 1996). Researching visitors' motivations in attending consumer exhibitions Rittichainuwat and Mair (2012) find "Get discounts and special promotions" as the major motivation. They also find the examination of products before making decision, collection of information for future purchases and buying products and services to be among top attendance motives. Authors generally agree about the difficulties in researching attendance motivations and mainly consider an event as trade fair, trade show or consumer exhibition. Therefore, motivations are grouped in relation to the type of visitors. The biggest difference in motivations is between trade show visitors and consumer exhibition visitors. In other words, that difference divides visitors into two main categories: buyers and non-buyers including several subcategories: business (those whose aim is to get in direct contact with exhibiting companies and discuss cooperation possibilities), professional (mainly attending seminars, workshops and press visitors), and the general public (those who simply want to spend a day exploring the exhibition with friends and family as a part of leisure, cultural and educational activities). Some authors find in their studies that trade show visitors are mainly non-buyers and not interested in any purchase (Kepf, Smith, 1998; Borghini et al., 2006), while 
some authors identify trade show visitors as buyers: short-term buyers, long-term buyers, prospective buyers, current buyers and non-buyers (Godar, 1992; Godar, O’Connor 2001). Furthermore, Tanner et al. (2001) in their study classify trade show visitors as total visitors (those who consider both purchase and non-purchase activities important and also plan to buy a product or service during the fair or after it), self-developers (whose aim is networking and seminars attendance in order to develop their career), shoppers and browsers. In their study, Lee et al. (2010) suggest that visitors can be divided into three major categories by their non-buying motivations: seeing a particular product or companies, gathering information and building their networks. Among those visitors who primarily attend the exhibition with nonpurchase motives Borghini et al. (2006) identifies suppliers, competitors and representatives of companies in related field.

\section{Do we have the same motives? Exhibitors vs. visitors}

Trade fairs are generally seen as a "must show up" place where exhibitors focus on achieving sales objectives. By Blythe and Rayner (1996) those objectives are: generating leads, closing sales and making new contacts with buyers. As mentioned in previous paragraphs, not every visitor is also a buyer and therefore sales-only-oriented exhibit could lead to dissatisfaction and not meeting both exhibitors' and visitors' expectations. Many studies reveal unawareness of exhibitors about this fact (Bello, Lohita, 1993; Gramman, 1993; Blythe, Rayner, 1996; Munuera, Ruiz, 1999; Skerlos, Blythe, 2000) which could be a consequence of the gap between motives of the two parties. Exhibitors simply have to deal with visitors with totally different motives and to find a strategy to isolate their focus group of visitors. Blythe (2010) presents those visitors as: Tyre kickers (those with no intention of buying and no power to do so), Wheeler-dealers (those who have the power to buy but want to negotiate in first place and to search for the best offer), Technocrats (those who are looking for technology innovations), Foxes (those with motives to sell something to exhibitors) and Day-trippers (usually retired people, students, families and others who see an exhibition as a nice opportunity to spend a day out and find some entertainment). In simple terms, exhibitors need to focus on a small group of visitors accounting for 10 per cent or less (Bello, Lohita, 1993; Gramman, 1993; Munuera, Ruiz, 1999; Skerlos, Blythe, 2000). Blythe (2002) adds that exhibitors are ignoring the possibilities arising from interaction with the other 90 per cent of visitors. In addition to those findings, Tanner et al. (2001) state that non-buyers should not be underestimated since they may become long-term buyers. Previous studies show that exhibitors at trade fairs can have more objectives such as: sales, promotion, market research and strategic benefit related activities (Blythe, 1997; Tanner, 2002; Hansen, 2004). Apart from these objectives one of the main goals is certainly extending business network. In other words, those exhibitors who decided to participate in the trade fair or any similar exhibition due to various motives are more likely to provide a better response to visitors' needs, fulfil both own and visitor's expectations and to meet required satisfaction level.

New motives can arise after the first attendance or participation in the exhibition or from the experiences of other visitors. Visitors therefore can have different motives for attending the same or similar event. By changing or extending the motives and priorities visitors move from one to another previously classified groups. In some cases they simply fit to more than just 
one group. The same theory could be applicable in regards to exhibitors. Profile of exhibitors and quality and quantity of visitors can initiate the change of motivation. On the other hand, positive visit or exhibit outcome can initiate repeat participation.

Table 2. Previous researches on similar events

\begin{tabular}{|c|c|c|}
\hline Author(s) & Event profile & Identified attendance motives \\
\hline $\begin{array}{l}\text { Breiter, Milman } \\
(2006)\end{array}$ & US exhibitions & $\begin{array}{l}\text { Networking, learning about new products, viewing the quality of the } \\
\text { exhibition }\end{array}$ \\
\hline $\begin{array}{l}\text { Whitfield, Webber } \\
\text { (2011) }\end{array}$ & UK exhibition & $\begin{array}{l}\text { Meeting specialists, networking, finding out about new products, gaining } \\
\text { technical advice }\end{array}$ \\
\hline Kozak (2006) & $\begin{array}{l}\text { Travel and } \\
\text { hospitality } \\
\text { exhibitions }\end{array}$ & $\begin{array}{l}\text { Learning about new products, gathering information about new products } \\
\text { and companies, seeing particular products and companies }\end{array}$ \\
\hline Lee et al. (2010) & Trade show & $\begin{array}{l}\text { Market investigation, products comparison, testing/trying products, } \\
\text { information search }\end{array}$ \\
\hline $\begin{array}{l}\text { Kozak, Kayr } \\
(2009)\end{array}$ & $\begin{array}{l}\text { Trade show: } \\
\text { Tourism and travel } \\
\text { exhibition }\end{array}$ & Shopping and meeting new friends are the least important \\
\hline Tanner et al. (2001) & Trade show & $\begin{array}{l}\text { Purchasing, career development, attending seminars, finding about new } \\
\text { products and industry developments }\end{array}$ \\
\hline $\begin{array}{l}\text { Borghini et al. } \\
(2006)\end{array}$ & Trade show & $\begin{array}{l}\text { Verifying competitiveness of own products, collecting market } \\
\text { intelligence, being up to date with market trends }\end{array}$ \\
\hline Blythe (1999) & Trade exhibition & $\begin{array}{l}\text { Seeing new products and developments, obtaining technical or product } \\
\text { information, getting up-to-date information on legislation, trying new } \\
\text { products, seeing new products and companies, making business contacts, } \\
\text { talking to experts, comparing products }\end{array}$ \\
\hline $\begin{array}{l}\text { Godar, O’Connor } \\
\text { (2001) }\end{array}$ & Buyer trade show & $\begin{array}{l}\text { Short term: confirming decision, becoming advocate, receiving reward; } \\
\text { Long term: reinforcing contacts, developing contacts, supporting } \\
\text { industry }\end{array}$ \\
\hline $\begin{array}{l}\text { Munuera, Ruiz } \\
\text { (1999) }\end{array}$ & Trade fair & $\begin{array}{l}\text { Buying exhibited products, contacting suppliers, seeking new ideas, } \\
\text { finding out about competitors, discovering new products and obtaining } \\
\text { information, meeting specialists and comparing prices }\end{array}$ \\
\hline $\begin{array}{l}\text { Rittichainuwat, } \\
\text { Mair (2012) }\end{array}$ & $\begin{array}{l}\text { Consumer travel } \\
\text { exhibition }\end{array}$ & $\begin{array}{l}\text { Getting discounts and special promotions, examining products, } \\
\text { collecting information for future purchase, buying products and services, } \\
\text { gaining knowledge about new products, learning about new trends }\end{array}$ \\
\hline
\end{tabular}

Source: Authors' research

\section{The role of the exhibition organizers in meeting the participants'objectives}

Hybrid exhibitions are the meeting point of people from different walks of life. These people can have different motives for attending an exhibition. The objective of exhibition organizers is to create highly effective shows that result in positive outcomes for both exhibitors and visitors. Some might come to the exhibitions strictly for business purposes and others might only be interested in leisure activities. Whatever may be the reason for their visit, visitors are always on the lookout for something interesting and worth remembering. Therefore, the setting which allows matching predefined objectives with the achieved objectives of the visitors should be one of the organizers' priorities. If a predefined objective has been achieved, from visitor's point of view the exhibition is considered as successful. Organizers are aware of the fact that a friendly atmosphere can lead to higher effectiveness of the event and in relation to that many initiatives are undertaken. Creating effective and enjoyable event for all attendees, both exhibitors and visitors, organizers contribute in meeting their 
predefined expectations. Organizers can affect quantity and quality of exhibition attendance directly and indirectly. Exhibition location and entrance fees are mainly dependent on the organizer's market research and estimation. Tanner et al. (2001) also see those variables as certain barriers to visitors' attendance. The media represents another powerful tool that organizers frequently use to promote the events, draw exhibitors' and visitors' attention and create new motives for attendance.

\section{Hypotheses}

Based on these theoretical foundations and empirical studies, this paper proposed the following hypotheses:

Hypothesis 1. Motivation for visiting hybrid event differs among different groups of visitors.

Hypothesis 1a. Purchasing is a motive for hybrid event attendance.

Hypothesis 1b. Collecting information about new products, services and offers are motives for hybrid event attendance.

Hypothesis 1c. Attending seminars, meeting experts and finding business partners are motives for hybrid event attendance.

Hypothesis 1d. Leisure activities are motives for hybrid event attendance.

Hypothesis 2. Multiple clusters can be identified based on respondents' motive of the visit.

On the basis of the above literature review, main motives for visiting a trade show are buying, collecting information and business networking (Munuera, Ruiz, 1999; Borghini et al., 2006; Tanner et al., 2001). In the context of consumer exhibitions motivations are following: getting discounts and special promotions, examination of products and information collection (Rittichainuwat, Mair 2012).

\section{Methodology and sample characteristics}

Both qualitative and quantitative approach is used. Visitors of the previous exhibitions are surveyed and asked to write a list of their motives which played a main role in exhibition attendance. The major motives listed were: collecting information before the purchase and for future purchases, comparing products, buying, finding business partners, attending seminars, leisure activities. According to the literature review additional motives were found to have influence in visitors' participation in the exhibition and were included in the questionnaire. Motives are also compared to those found by Rittichainuwat and Mair (2012) in their study about consumer exhibition. By this comparison we found that many motives are overlapping, their position on the priority list is different though. Those findings are expected since this event is described as hybrid one which consolidates trade show, consumer exhibition, congress, sport and leisure activities in one event. Therefore, questions were slightly adapted to correspond to the exhibition theme. The final version of questionnaire was administered after consulting with exhibition organizers, congress centre managers and people from tourist organization had been done. 
The questionnaire was split into three sections: demographic profile of visitors, previous experience in relation to the visiting exhibition and list of motives. Five-point Likert scale ranging from 1 (strongly disagree) to 5 (strongly agree) was used to measure level of visitors' agreement with the statements. The survey was conducted at the $81^{\text {st }}$ International Agriculture Fair in May 2014. This exhibition is organized every year in May by Novi Sad Fair - professional exhibition and congress centre.

Visitors were surveyed in all areas of the fairground and in halls, especially in the main entrance hall when waiting to buy a ticket or when leaving. This provided a sample of attendees interested in buying machinery, livestock and other products and services, finding business partners, attending seminars, and in leisure activities.

The acquired data was processed with SPSS 17.0 software, using descriptive statistics, ANOVA analysis, factor analysis and hierarchical cluster analysis.

Table 3. Demographic information of respondents $(n=210)$

\begin{tabular}{|c|c|c|c|c|c|}
\hline Variables & \multirow{2}{*}{$\begin{array}{c}\text { Sample } \\
\text { size }\end{array}$} & \multirow{2}{*}{$\%$} & Variables & \multirow{2}{*}{$\begin{array}{c}\text { Sample } \\
\text { size }\end{array}$} & \multirow{2}{*}{$\%$} \\
\hline Age & & & Profession & & \\
\hline$\leq 20$ & 6 & 2.9 & Farmer & 72 & 34.3 \\
\hline $21-30$ & 30 & 14.3 & Entrepreneur & 60 & 28.6 \\
\hline $31-40$ & 83 & 39.5 & Government service employee & 14 & 6.7 \\
\hline $41-50$ & 59 & 28.1 & Professor/Expert & 6 & 2.9 \\
\hline $51-60$ & 28 & 13.3 & Retired person & 10 & 4.8 \\
\hline$\geq 61$ & 4 & 1.9 & Student/Pupil & 22 & 10.5 \\
\hline Gender & & & Unemployed & 8 & 3.8 \\
\hline Male & 156 & 74.3 & Press & 18 & 8.6 \\
\hline Female & 54 & 25.7 & First time visitor & & \\
\hline Education & & & Yes & 4 & 1.9 \\
\hline High school & 72 & 34.4 & No & 206 & 98.1 \\
\hline Faculty & 52 & 24.8 & Do you attend similar events? & & \\
\hline $\mathrm{Mr} / \mathrm{MSc}$ & 65 & 30.9 & Yes & 172 & 81.9 \\
\hline $\mathrm{PhD}$ & 21 & 9.9 & No & 38 & 18.1 \\
\hline
\end{tabular}

Source: Authors' calculation based on the survey data

Table 3 shows that the majority of visitors are in the age group of 31 to 50 years. So it is working age population mostly engaged in agriculture or entrepreneurship. Far more men than women visited the fair, which is understandable because agriculture is a demanding activity and does not represent a large sphere of interest among women.

The majority of visitors have a high school degree, and that is directly related to the fact that farmers were the most numerous among the visitors. Unfortunately, this shows that this is the category of the population with the lowest level of education. As one of the main reasons for this phenomena may be mentioned frequent leaving of the young people from villages and difficult economic situation in agriculture in Serbia for many years. Young people seem to be more interested in life in towns than staying in villages. Over $98 \%$ of visitors are not at the fair for the first time. Considering that this event has a long tradition and it is one of the 
largest events of its kind in the region, this is a unique opportunity to be engaged in some of the activities presented in Table 1. It is encouraging to note that vast majority of visitors also visits other similar events, which shows their active approach to learning and following new trends.

\section{Results and discussion}

\section{Reliability and validity analysis}

The factor analysis was conducted to verify the construct validity of the questionnaire and Cronbach's $\alpha$ value for each factor was computed to verify the reliability. The factor analysis was based on the principal component analysis with varimax rotation. In this study, all factors with eigenvalue greater than 1 and with factor loadings more than 0.5 were retained. The results of the factor analysis, which suggested a four-factor solution, included 14 items and explained 79.026 per cent of the variance. The Kaiser - Meyer - Olkin (KMO) overall measure of sampling adequacy was 0.795 which was middling (Kaiser, 1974) and Bartlett's test of Sphericity was significant $(p=0.000)$. The results of the factor analysis produced a clean factor structure with relatively higher loadings on the appropriate factors. Cronbach's $\alpha$ values for each factor were greater than 0.8 . The results showed that the Alpha coefficients of the four factors ranged from 0.823 to 0.916 . This demonstrates that the scales of the formal questionnaire have considerable reliability (Nunnally, 1978). Table 4 shows the results of the factor analysis.

Table 4. Results of factor analysis

\begin{tabular}{|c|c|c|c|c|c|}
\hline Extracted factors & Items & $\begin{array}{l}\text { Factor } \\
\text { loading }\end{array}$ & Eigenvalue & $\begin{array}{r}\text { Variance } \\
\text { explained }\end{array}$ & Cronbach's $\alpha$ \\
\hline \multirow{4}{*}{ F1 - Purchase } & $\begin{array}{l}\text { Buying livestock, products and } \\
\text { services }\end{array}$ & 0.836 & \multirow{4}{*}{4.868} & \multirow{4}{*}{23.170} & \multirow{4}{*}{0.898} \\
\hline & $\begin{array}{l}\text { Examining products before } \\
\text { purchase }\end{array}$ & 0.914 & & & \\
\hline & $\begin{array}{l}\text { Collecting information for } \\
\text { further purchases }\end{array}$ & 0.810 & & & \\
\hline & $\begin{array}{l}\text { Getting discounts and special } \\
\text { promotions }\end{array}$ & 0.875 & & & \\
\hline \multirow{3}{*}{ F2 - Information } & $\begin{array}{l}\text { Getting acquainted with } \\
\text { innovations }\end{array}$ & 0.858 & \multirow{3}{*}{3.717} & \multirow{3}{*}{22.966} & \multirow{3}{*}{0.916} \\
\hline & $\begin{array}{l}\text { Learning about new trends in } \\
\text { agriculture }\end{array}$ & 0.903 & & & \\
\hline & $\begin{array}{l}\text { Gaining knowledge about new } \\
\text { products }\end{array}$ & 0.890 & & & \\
\hline \multirow{4}{*}{$\begin{array}{l}\text { F3 - Education and } \\
\text { Business }\end{array}$} & $\begin{array}{l}\text { Attending seminars and } \\
\text { workshops }\end{array}$ & 0.621 & \multirow{4}{*}{1.464} & \multirow{4}{*}{18.186} & \multirow{4}{*}{0.804} \\
\hline & Meeting experts & 0.874 & & & \\
\hline & Exchanging ideas with others & 0.802 & & & \\
\hline & Finding new business partners & 0.636 & & & \\
\hline \multirow[t]{3}{*}{ F4 - Leisure } & $\begin{array}{l}\text { Watching sports and } \\
\text { entertaining programs }\end{array}$ & 0.809 & \multirow{3}{*}{1.016} & \multirow{3}{*}{14.704} & \multirow{3}{*}{0.823} \\
\hline & Valuable prizes for visitors & 0.871 & & & \\
\hline & Leisure activities & 0.619 & & & \\
\hline
\end{tabular}

Source: Authors' calculation based on the survey data 
The first factor was labelled "Purchase". This factor explained $23.170 \%$ of the total variance with a reliability coefficient of 0.898 . The second factor was "Information" explaining $22.966 \%$ of the total variance with a reliability coefficient of 0.916 . The third factor was labelled "Education and Business" and explained $18.186 \%$ of the variance with a reliability coefficient of 0.804 . The fourth factor, labelled "Leisure" accounted for $14.704 \%$ of the variance with a reliability coefficient of 0.823 .

The results of descriptive statistical analysis (Table 5) show that visitors gave the highest significance to the first factor "Purchase" with mean rating 3.404. Unlike other trade fairs and exhibitions, where main motives are finding business partners and getting discounts and promotions, visitors to International Agriculture Fair put an emphasis on buying. Getting discounts and special promotions is certainly among "Purchase" items. However, this item scored the lowest mean rating of 3.286. Next in importance are second and third factors "Information" and "Education and Business". The lowest rated factor is "Leisure" due to small number of visitors who primarily show interest in leisure activities.

Table 5. Mean ratings of factors and items

\begin{tabular}{|l|c|c|}
\hline \multicolumn{1}{|c|}{ Extracted factors and items } & Mean & Std. Dev. \\
\hline \multicolumn{1}{|c|}{ F1 - Purchase } & $\mathbf{3 . 4 0 4}$ & $\mathbf{1 . 0 5 3 5}$ \\
\hline Buying livestock, products and services & 3.438 & 1.2173 \\
\hline Examining products before purchase & 3.505 & 1.2149 \\
\hline Collecting information for further purchases & 3.390 & 1.1533 \\
\hline Getting discounts and special promotions & 3.286 & 1.2274 \\
\hline \multicolumn{1}{|c|}{ F2 - Information } & $\mathbf{3 . 3 3 0}$ & $\mathbf{0 . 9 2 8 6}$ \\
\hline Getting acquainted with innovations & 3.333 & 0.9651 \\
\hline Learning about new trends in agriculture & 3.343 & 1.0337 \\
\hline Gaining knowledge about new products & 3.314 & 1.0101 \\
\hline \multicolumn{1}{|c|}{ Fducation and Business } & $\mathbf{0 . 9 3 4 5}$ \\
\hline Attending seminars and workshops & $\mathbf{3 . 1 2 6}$ & 1.1473 \\
\hline Meeting experts F4 - Leisure & 2.848 & 1.1612 \\
\hline Exchanging ideas with others & 3.029 & 1.0017 \\
\hline Finding new business partners & 3.143 & 1.3703 \\
\hline \multicolumn{1}{|c|}{ | } & 3.486 & $\mathbf{0 . 9 0 8 3}$ \\
\hline Watching sports and entertaining programs & $\mathbf{2 . 5 1 4}$ & 1.1220 \\
\hline Valuable prizes for visitors & 2.848 & 0.8687 \\
\hline Leisure activities & 2.143 & 1.1573 \\
\hline
\end{tabular}

Source: Authors' calculation based on the survey data

When analyzing the data, four factors that are consistent with the hypotheses clearly stood out, or in other words, they confirm the initial assumption. The largest number of visitors belongs to the category of farmers. Therefore, it is understandable that the first factor is shown as the most significant. Within the first factor four items were extracted and one of them is also the most common reason for visiting the fair: Examining products before purchase (3.505). 
Table 6. Results of ANOVA analysis

\begin{tabular}{|l|c|c|c|c|}
\hline \multirow{2}{*}{ Respondent category } & \multicolumn{4}{c|}{ Means by factors } \\
\cline { 2 - 5 } & F1 & F2 & F3 & F4 \\
\hline 1. Farmer & 41.076 & 37.778 & 34.236 & 26.759 \\
\hline 2. Entrepreneur & 31.875 & 33.556 & 32.917 & 19.333 \\
\hline 3. Government service employee & 25.714 & 33.810 & 38.571 & 17.619 \\
\hline 4. Professor/ Expert & 20.000 & 43.333 & 42.500 & 12.222 \\
\hline 5. Pensioner & 32.500 & 20.000 & 15.500 & 41.333 \\
\hline 5. Student/ Pupil & 33.295 & 25.152 & 22.727 & 31.515 \\
\hline 6. Unemployed person & 32.361 & 25.926 & 25.556 & 31.481 \\
\hline 7. Press people & 20.000 & 38.333 & 26.875 & 25.000 \\
\hline F-value & 14.235 & 16.148 & 18.514 & 26.436 \\
\hline Scheffe test & $1>2,3,4,7$ & $4>5,6,7$ & $4>5,6,7,8$ & $5>1,2,3,4,8$ \\
\hline
\end{tabular}

Source: Authors' calculation based on the survey data;

Note: $\mathrm{p}<0.01$

Analysis of variance ANOVA (Table 6), compared to profile of visitors, show a statistically significant difference in scores at all factors. The results of post-hoc Scheffe's test show that farmers provide statistically significantly greater importance to the first factor "Purchase" compared to the entrepreneurs, government service employees and professors/experts in the field of agriculture and the unemployed visitors. Professors/experts in the field of agriculture give statistically significantly greater importance to "Information" factor in comparison to the pensioners, students and unemployed visitors. Furthermore, professors/ experts give higher importance to "Education and Business" factor than pensioners, students, unemployed and the press people. Fourth factor, "Leisure" was marked as the most important one by pensioners, which makes a significant difference in relation to farmers, entrepreneurs, government service employees, professors/experts in the field of agriculture and the press people.

By using hierarchical cluster analysis (Table 7), the respondents are grouped based on motives of visit. The method of Euclidean squared distance was applied. After the dendrogram analysis two clusters were reta0ined: Cluster $1(n=104)$ and Cluster $2(n=106)$. Further canonical discriminative analysis $(\lambda=0.355, \mathrm{R}=0.803, \mathrm{p}<0.001)$ identified the clusters more precisely.

Table 7. Cluster analysis

\begin{tabular}{|l|c|c|c|c|}
\hline \multirow{1}{*}{ Groups/factors } & Wilks' Lambda & \multirow{2}{*}{ F } & \multirow{2}{*}{ Sig. } & $\begin{array}{c}\text { Structure } \\
\text { matrix }\end{array}$ \\
\cline { 3 - 5 } & & & & Function 1 \\
\hline Purchase & 0.917 & 18.739 & 0.000 & 0.583 \\
\hline Information (Cluster 2) & 0.875 & 29.842 & 0.000 & -0.281 \\
\hline Education and Business & 0.945 & 12.120 & 0.001 & 0.223 \\
\hline Leisure (Cluster 1) & 0.619 & 128.271 & 0.000 & 0.179 \\
\hline
\end{tabular}

Source: Authors' calculation based on the survey data 
The respondents from Cluster 1 can be described as those who visit hybrid event in order to spend leisure time, while the Cluster 2 groups respondents whose primary motive of visit is collecting information.

Regarding the gender, it was found that male population is dominant in both clusters (76.9\% and $71.7 \%$, respectively). In terms of age of the respondents, the findings are very similar to general sample characteristics. The majority of the respondents in both clusters are in the age group of 31 to 50 years (53.8\% in Cluster 1 and $81.1 \%$ in Cluster 2). As mentioned before, working age population is mostly engaged in agriculture or entrepreneurship and these results are somewhat expected - over $80 \%$ of the respondents who visited the event in order to collect the information, belong to this age group. It is also noticed a higher percentage of the respondents in groups of 51 to 60 years $(21.2 \%)$ and over 60 years (3.8\%) in Cluster 1 than in the same age groups in Cluster $2(5.7 \%$ and $0 \%$, respectively). It means that elderly people visited the event mainly with leisure motives (e.g. retired people, older farmers).

Further analysis of the respondents' education level from both clusters reveals that the biggest difference is in the number of visitors with $\mathrm{PhD}$ degree. Only four visitors $(3.8 \%)$ are present in Cluster 1, while in Cluster 2 there are 18 (17\%) visitors with $\mathrm{PhD}$ degree. Highly educated people are more interested in collecting new information and establishing contacts than in leisure activities. It is probably due to their working positions and job specifications. Regarding the respondents' profession, farmers are dominant group in Cluster 1 (50\%), followed by entrepreneurs (15.4\%). On the other hand, it is vice versa situation in Cluster 2; the most dominant are entrepreneurs (41.5\%), and the farmers follow (18.9\%). Additionally, government service employees represent only $1.9 \%$ share in Cluster 1 and $11.3 \%$ in Cluster 2, which can be also linked to their work obligations.

Finally, $98.1 \%$ of the respondents from both clusters are not the first time visitors. However, somewhat smaller number of visitors $(73.1 \%)$ from Cluster 1 visits similar events in comparison to $90.6 \%$ of the respondents from Cluster 2. Therefore, it is not surprising that those visitors who primarily collect information also visit similar events.

These research findings indicate that it is possible to accept the initial hypotheses:

$\mathbf{H}_{1 \mathbf{a}}$ : The purchasing is the most important motive for farmers and end users of the exhibited products and services. In this way, they provide themselves the basic funding - machinery, equipment and tools. Buying under favorable conditions and a large selection of products in one place is certainly one of the main reasons why farmers give the most attention to this factor. It is interesting that students and pensioners are next on the list of those who gave significant importance to the first factor. Obviously, those categories of visitors are low budget end users with low purchasing powers, but they are mainly interested in buying cheaper things such as souvenirs, food products, pets, etc.

$\mathbf{H}_{\mathbf{1 b}}$ : The second motive is singled out as very significant for farmers, entrepreneurs, government service employees and press people. It is understandable that the farmers gave high importance to this factor, because gathering information is the phase that usually 
precedes purchasing. However, it is interesting that the professors and other experts are those who gave the strongest importance to this factor. This could be attributed to the desire to be up to date with new technical and technological developments and trends in the field of their interest in order to transmit new knowledge through their lectures. Press people, in relation to other factors, put far more importance on gathering information, which is not surprising given the fact that this is the core of their business activities.

$\mathbf{H}_{1 \mathbf{c}}$ : This is also the motive that has received the greatest importance by professors and experts. Considering the fact that apart from education, this factor includes business segment, great importance is also received by government service employees in first place, followed by farmers and entrepreneurs. Finding new business partners and exchanging ideas with others are the leading motives, whereas the item with lowest score is attending seminars and workshops. These findings could be attributed to disproportionate number of above mentioned categories in surveyed sample on one hand and the lack of time or interest in attending seminars among farmers.

$\mathbf{H}_{\mathbf{1 d}}$ : Leisure activities are the main reason for visiting the event for pensioners, students, pupils and unemployed people. Not having business obligations brings more possibilities to organize free time in better way. Hybrid character of the event and various supporting activities, attract the widest general public offering quality in spending leisure time. As an additional confirmation of the factor's importance could be pointed out Mean (4.1333) received by pensioners, representing the third highest.

$\mathbf{H}_{\mathbf{1}}$ : By accepting four second level hypotheses, the initial hypothesis can be also accepted. It is confirmed through performed statistical analyses that motivation for visiting hybrid event differs among different groups of visitors.

$\mathbf{H}_{2}$ : Since two clusters can be identified, based on respondents' motive of the visit (leisure and information), the proposed hypothesis can be accepted.

The presented results show that visitors of this hybrid event have different motives for the visit. Looking at the motives of all visitors, the most dominant motives are: Examining products before purchase, Finding business partners and Buying livestock, products and services. This is quite expected since this event has mainly elements of trade show and consumer exhibition. Similar findings are presented by Tanner et al. (2001) in their paper, where trade show "Shopper" category visitors have "purchasing" as a dominant motive. Browning and Adams (1988) also found in their research that finding business partners is important in trade show industry. This item received a very high mean (3.486) which puts it on the second place on the list. This can be explained by the large number of farmers $(34.3 \%)$ and entrepreneurs (28.6\%) among the visitors. Apart from buying livestock, machinery and other equipment, farmers are also looking for food processing companies in order to sell their agriculture products. On the other hand, entrepreneurs are interested in companies that need new dealers or suppliers or just to learn about new trends and competition's offer. Rittichainuwat and Mair (2012) found in their study that most consumer exhibition visitors have a purchase motives whereas Bello (1992), Bello, Lohtia (1993) and Borghini et al. (2006) found that most trade show visitors have weak purchasing motives. Interesting thing is that results of this study can 
describe International Agriculture Fair as a trade show ("Finding business partners" scored the second highest mean), but also as a consumer exhibition ("Examining products before purchase" and "Buying livestock, products and services" scored the first and third means, respectively) - confirming its previously described character of the hybrid event.

\section{Practical implications, limitations, and future research}

The International Agriculture Fair has a long tradition and therefore it is a "must visit" event for farmers in first place followed by other categories of visitors. The fair is regularly visited by parents with their young children in order to get acquainted with domestic animals. For students and retired people, this event makes a good way to spend a leisure time.

Results show that pensioners gave the greatest significance to the fourth factor. They see this event as a leisure time activity in first place. Students and unemployed people have similar opinion about the fair and they gave high marks to this factor. Therefore, it is possible to classify them under same category with pensioners. Many supporting activities present a main reason for visit in relation to aforementioned visitor category and make this event widely recognizable.

These facts could be related to the study conducted by Berne and Uceda-Garcia (2008) which showed that the content and concept of the event have an impact on process of making a decision about visiting a particular event.

In recent years, the fair is organized in cooperation with partner countries and exhibitors from those particular countries are numerous. Furthermore, it opens up many opportunities for all categories of visitors. This can be directly correlated with the result of the study and the fact that the most important motive for visiting the fair was examining products before purchase.

Based on personal participation in the organization of trade shows, and discussions with exhibitors, it was found that a large number of visitors who mainly explore and learn about the products and services, also decide to make a purchase during the fair or shortly after it.

In the foreground is the question of farmers who buy tractors and other machinery, equipment, tools, animals or chemical products. Certainly, this was due to the promotions and discounts during the fair, which is confirmed in the first factor - getting discounts and promotions. The presence of new exhibitors, especially from foreign countries goes in favour of the first factor since discounts and promotions are the main tool in attracting the target audience.

The current state of the world economy, slow economic growth and high competition are forcing the organizers of such events to explore the needs of exhibitors and visitors. Exhibition companies often guarantee a large number of visitors (Cox et al., 1986). Furthermore, Godar and O'Connor (2001) found in their study that identification and understanding of visitors' motivations to attend the trade show are keys for exhibitor in fulfilling their objectives.

This research provides guidelines for better understanding visitors' motivations to visit a 
hybrid event. Since the line between trade show and consumer exhibition becomes thinner, such events could be a good example for event managers to balance between exhibitors' and visitors' motivations and needs. The results of the study also suggest that gathering information, learning about new trends and meeting experts are significant motivations and therefore organizers of such events should include those market segments while making a marketing strategy. Finally, supporting activities could be a good magnet for general public and a way how to spend leisure time. Exhibitors whose aim is mainly selling of goods and services have the major benefit from that. Organizers of hybrid events must bear in mind that such complex exhibitor structure requires attraction of visitors of different profiles professional and general public.

The managerial implications can be observed from two different perspectives: for the event organizers this information is useful for future strategy planning on how to attract new visitors and indirectly exhibitors. Knowing the major motivations, organizers can improve particular event segments or even extend its portfolio. On the other hand, exhibitors will be able to plan their business activities towards the visitors' needs. This will help both sides in fulfilling the objectives. With these information organizers can create an event with better competitiveness which is crucial since many stakeholders are part of it.

This paper suggests future research in the area of visitors' motivations to visit hybrid events of a different theme, and also exhibitors' objectives while participating at such event. Further research may include exhibitors' actions in order to evaluate and choose the right event for their attendance. Future research may also examine organizers' strategies in balancing between participants' demands.

Regarding the limitations of this study, some notes should be discussed. There is a lack of research related to hybrid events of any kind. This study examined only one event and therefore results can not be applicable to other events with different themes without additional research and comparison. This study is exploratory and offers results as a base for further research.

Hybrid events are a good way to meet various stakeholders at one place. Exhibitors can use them as a strong and effective marketing tool for company promotion, the direct sale of products and services or to find new business partners. However, the major role should be played by organizers in order to have a successful event - repeat and new exhibitors and visitors on one side and economic benefit on the other. 


\section{References}

1. Bello, D. (1992): Industrial buyer behavior at trade shows: implications for selling effectiveness, Journal of Business Research, vol. 25, no. 1, pp. 59-80.

2. Bello, D., Lohita, R. (1993): Improving trade show effectiveness by analyzing attendees, Industrial Marketing Management, vol. 22, no. 4, pp. 311-318.

3. Berne, C., Garcia-Uceda, M. E. (2008): Criteria involved in evaluation of trade shows to visit, Industrial Marketing Management, vol. 37, pp. 565-579.

4. Blythe, J. (1997): Does size Matter? Objectives and measures at UK trade exhibitions, Journal of Marketing Communications, vol. 3, no. 1, pp. 51-59.

5. Blythe, J. (1999): Visitor and exhibitor expectations and outcomes at trade exhibitions, Marketing Intelligence and Planning, vol. 17, no. 2, pp. 100-108.

6. Blythe, J. (2002): Using trade fairs in key account management, Industrial Marketing Management, vol. 31, no. 7, pp. 627-635.

7. Blythe, J. (2010): Trade fairs as communication: a new model, Journal of Business and Industrial Marketing, vol. 25, no. 1, pp. 57-62.

8. Blythe, J., Rayner, T. (1996): The evaluation of non-selling activities at British trade exhibitions: an exploratory study, Marketing Intelligence and Planning, vol. 14, no. 5, pp. 20-24.

9. Borghini, S. Golfetto, F., Rinallo, D. (2006): Ongoing industrial buyers, Journal of Business Research, vol. 59, pp. 1151-1159.

10. Breiter, D., Milman, A. (2006): Attendees'needs and service priorities in a large convention center: application of the importance-performance theory, Tourism Management, vol. 27, pp. 1364-1370.

11. Browning, J., Adams, R. (1988): An effective promotional tool for the small industrial business, Journal of Small Business Management, vol. 26, no. 4, pp. 31-36.

12. Carlsen, J., Taylor, A. (2003): Mega-Events and Urban Renewal: The case of the Manchester 2002 Commonwealth Games, Event Management, vol. 8, pp. 15-22.

13. Cox, J. M., Sequeira, I. K., Bock, L. L. (1986): Trade show trends. Audience quality remains high, Business Marketing, vol. 5, pp. 108-114.

14. Crompton, J. L. (1979): Motivations for pleasure vacation, Annals of Tourism Research, vol. 6, no. 4, pp. 408-424.

15. Crompton, J. L., McKay, S. L. (1997): Motives of visitors attending festival events, Annals of Tourism Research, vol. 24, no. 2, pp. 425-439.

16. Dudley, J. W. (1990): Successful Exhibiting, Kogan-Page, London.

17. Dwyer, R., Tanner, J. F., Jr. (1999): Business marketing: Connecting strategy, relationship, and learning, Irwin McGraw-Hill, San Francisco.

18. Fredline, L., Jago, L., Deery, M. (2003): The development of a generic scale to measure the social impacts of events, Event Management, vol. 8, no. 1, pp. 23-37. 
19. Getz, D. (1997): Event Management and Event Tourism, Cognizant Communications Corp., New York.

20. Getz, D. (2008): Event tourism: definition, evolution and research, Tourism Management, vol. 29, no. 3, pp. 403-428.

21. Godar, S. H. (1992): Same time next year? Why industrial buyers go to trade shows, in: R. L. King (Ed.), Proceedings of the Southern Marketing Association - Marketing perspective for the 1990s, Richmond, The Southern Marketing Association, pp. 33-37.

22. Godar, S. H., O’Connor, P. J. (2001): Same time next year - buyer trade show motives, Industrial Marketing Management, vol. 30, no. 1, pp. 77-86.

23. Gómez, J. C., Mas, F., Munuera, J. L. (1992): Aproximación al Mercado Ferial in España, In Distribución Comercial Internacional, Paloma Taltavull, Ed., Valencia, Generalitat Valenciana.

24. Gramman, J. (1993): Independent market research, Birmingham, National Exhibition Centre.

25. Hansen, K. (2004): Measuring performance at trade shows. Scale development and validation, Journal of Business Research, vol. 57, no. 1, pp. 1-13.

26. Hiller, H. (1998): Assessing the impact of mega events: a linkage model, Current Issues in Tourism, vol. 1, no. 1, pp. 47-57.

27. Kaiser, H. F. (1974): An index of factorial simplicity, Psychometrika, vol. 39, pp. 31-36.

28. Kepf, D. S., Smith, R. E. (1998): Consumer processing of product trial and the influence of prior advertising: a structural modeling approach, Journal of Marketing Research, vol. 35, no. 3, pp. 325-328.

29. Kozak, N. (2006): The expectations of exhibitors in tourism, hospitality and the travel industry, Journal of Convention and Event Management, vol. 7, no. 3, pp. 99-116.

30. Kozak, N., Kayr, C. H. (2009): Visitors'objectives for trade show attendance: a case study on the East Mediterranean international tourism and travel exhibition (EMITT), Event Management, vol. 12, pp. 1-17.

31. Lee, M. J., Yeung, S., Dewald, B. (2010): An exploratory study examining the determinants of attendance motivations as perceived by attendees at Hong Kong exhibitions, Journal of Convention and Event Tourism, vol. 11, pp. 195-208.

32. Ling Yee, L. (2007): Marketing resources and performance of exhibitor firms in trade show: a contingent resource perspective, Industrial Marketing Management, vol. 36, vol. 3, pp. 360-370.

33. Mansfeld, Y. (1992): From motivation to actual travel, Annals of Tourism Research, vol. 19, no. 3, pp. 399-419.

34. Munuera, J. L., Ruiz, S. (1999): Trade Fairs as Services: A Look at Visitors'Objectives in Spain, Journal of Business Research, vol. 44, pp. 17-24.

35. Nunnally, J. C. (1978): Psychometric theory, McGraw-Hill, New York.

36. Pearce, D. G. (2007): Supplier selection in New Zealand inbound tourism industry, 
Journal of Travel and Tourism Marketing, vol. 23, no. 1, pp. 57-68.

37. Pearce, P. L. (1982): The Social Psychology of Tourist Behavior, Pergamon Press, Oxford.

38. Reeder, R. R., Brierty, E. G., Reeder, B. H. (1991): Industrial Marketing Analysis, Planning, and Control, $2^{\text {nd }}$ Ed. Englewood Cliffs, Prentice Hall, New Jersey.

39. Rittichainuwat, B., Mair, J. (2012): Visitor attendance motivations at consumer travel exhibitions, Tourism Management, vol. 33, no. 5, pp. 1236-1244.

40. Rosson, P. J., Seringhaus, F. H. R. (1995): Visitor and exhibitor interaction at industrial trade shows, Journal of Business Research, vol. 32, no. 1, pp. 81-90.

41. Sharland, A., Balgoh, P. (1996): The value of nonselling activities at international trade shows, Industrial Marketing Management, vol. 25, no. 1, pp. 59-66.

42. Skerlos, K., Blythe, J. (2000): Ignoring the audience: exhibitors and visitors at a Greek trade fair, Proceedings of the $5^{\text {th }}$ Annual Conference on Corporate and Marketing Communication, 22-23 May, Rotterdam, Erasmus University.

43. Tanner, J. F., Chonko, L. B., Ponzurick, T. V. (2001): A learning model of trade exhibition attendance, Journal of Convention and Exhibition Management, vol. 3, no. 3, pp. 3-26.

44. Tanner, J. F. Jr. (2002): Levelling the playing field: factors influencing trade show success for small companies, Industrial Marketing Management, vol. 31, no. 3, pp. 229-239.

45. Thrane, C. (2002): Jazz festival visitors and their expenditures: Linking spending patterns to musical interest, Journal of Travel Research, vol. 40, pp. 281-286.

46. Uysal, M., Gahan, L., Martin, B. (1993): An examination of event motivations: A case study, Festival Management and Event Tourism, vol. 1, no. 1, pp. 5-10.

47. Whitfield, J., Webber, D. J. (2011): Which exhibition attributes create repeat visitation? International Journal of Hospitality Management, vol. 30, pp. 439-447.

Appendix

Survey Instrument (constructed by authors)

a) Socio-demographic part

\begin{tabular}{|c|c|c|c|c|c|}
\hline Gender & Age & Profession & Education & $\begin{array}{l}\text { First time } \\
\text { visitor? }\end{array}$ & $\begin{array}{l}\text { Do you } \\
\text { attend } \\
\text { similar } \\
\text { events? }\end{array}$ \\
\hline $\begin{array}{l}\text { 1) } M \\
\text { 2) } F\end{array}$ & $\begin{array}{l}\text { 1) } \leq 20 \\
\text { 2) } 21-30 \\
\text { 3) } 31-40 \\
\text { 4) } 41-50 \\
\text { 5) } 51-60 \\
\text { 6) } \geq 61\end{array}$ & $\begin{array}{l}\text { 1) Farmer } \\
\text { 2) Entrepreneur } \\
\text { 3) Government service employee } \\
\text { 4) Professor/Expert } \\
\text { 5) Retired person } \\
\text { 6) Student/pupil } \\
\text { 7) Unemployed } \\
\text { 8) Press }\end{array}$ & $\begin{array}{l}\text { 1) High school } \\
\text { 2) Faculty } \\
\text { 3) } \mathrm{Mr} / \mathrm{MSc} \\
\text { 4) } \mathrm{PhD} \\
\text { 5) }\end{array}$ & $\begin{array}{l}\text { 1) Yes } \\
\text { 2) No }\end{array}$ & $\begin{array}{l}\text { 1) Yes } \\
\text { 2) No }\end{array}$ \\
\hline
\end{tabular}


b) Visitors' motives: 1 (strongly disagree); 5 (strongly agree)

\begin{tabular}{|l|l|}
\hline Motives for visiting the event & Agreement level \\
\hline Buying livestock, products and services & 12345 \\
\hline Examining products before purchase & 12345 \\
\hline Collecting information for further purchases & 12345 \\
\hline Getting discounts and special promotions & 12345 \\
\hline Getting acquainted with innovations & 12345 \\
\hline Learning about new trends in agriculture & 12345 \\
\hline Gaining knowledge about new products & 12345 \\
\hline Attending seminars and workshops & 12345 \\
\hline Meeting experts & 12345 \\
\hline Exchanging ideas with others & 12345 \\
\hline Finding new business partners & 12345 \\
\hline Watching sports and entertaining programs & 12345 \\
\hline Valuable prizes for visitors & 12345 \\
\hline Leisure activities & 12345 \\
\hline
\end{tabular}

